\title{
Influence of the Water Source on the Carbon Footprint of Irrigated Agriculture: A Regional Study in South-Eastern Spain
}

\author{
Bernardo Martin-Gorriz (D), Victoriano Martínez-Alvarez (D), José Francisco Maestre-Valero (D) \\ and Belén Gallego-Elvira *D
}

Agricultural Engineering Center, Technical University of Cartagena, Paseo Alfonso XIII 48, 30203 Cartagena, Spain; b.martin@upct.es (B.M.-G.); victoriano.martinez@upct.es (V.M.-A.); josef.maestre@upct.es (J.F.M.-V.)

* Correspondence: belen.gallego@upct.es; Tel.: +34-968177731

Citation: Martin-Gorriz, B.;

Martínez-Alvarez, V.; Maestre-Valero,

J.F.; Gallego-Elvira, B. Influence of the Water Source on the Carbon Footprint of Irrigated Agriculture: A Regional Study in South-Eastern Spain. Agronomy 2021, 11, 351. https:// doi.org/10.3390/agronomy11020351

Academic Editor: Benjamin D. Duval, Sarah C. Davis and Darren Drewry Received: 29 December 2020

Accepted: 13 February 2021

Published: 16 February 2021

Publisher's Note: MDPI stays neutral with regard to jurisdictional claims in published maps and institutional affiliations.

Copyright: (c) 2021 by the authors. Licensee MDPI, Basel, Switzerland. This article is an open access article distributed under the terms and conditions of the Creative Commons Attribution (CC BY) license (https:// creativecommons.org/licenses/by/ $4.0 /)$.

\begin{abstract}
Curbing greenhouse gas (GHG) emissions to combat climate change is a major global challenge. Although irrigated agriculture consumes considerable energy that generates GHG emissions, the biomass produced also represents an important $\mathrm{CO}_{2}$ sink, which can counterbalance the emissions. The source of the water supply considerably influences the irrigation energy consumption and, consequently, the resulting carbon footprint. This study evaluates the potential impact on the carbon footprint of partially and fully replacing the conventional supply from Tagus-Segura water transfer (TSWT) with desalinated seawater (DSW) in the irrigation districts of the Segura River basin (south-eastern Spain). The results provide evidence that the crop GHG emissions depend largely on the water source and, consequently, its carbon footprint. In this sense, in the hypothetical scenario of the TSWT being completely replaced with DSW, GHG emissions may increase by up to $50 \%$ and the carbon balance could be reduced by $41 \%$. However, even in this unfavourable situation, irrigated agriculture in the study area could still act as a $\mathrm{CO}_{2}$ sink with a negative total and specific carbon balance of $-707,276 \mathrm{t} \mathrm{CO}_{2}$ /year and $-8.10 \mathrm{t} \mathrm{CO}_{2}$ /ha-year, respectively. This study provides significant policy implications for understanding the water-energy-food nexus in water-scarce regions.
\end{abstract}

Keywords: agricultural irrigation; climate change; GHG emissions; carbon removal; water transfer; desalination; water-energy nexus

\section{Introduction}

Anthropogenic greenhouse gas (GHG) emissions are the key driver of climate change [1]. Population growth, economic prosperity and evolving dietary demands are increasing the demand for food. The way we produce and consume (intensive farming systems, water and soil depletion, high levels of greenhouse gas emissions, etc.) needs profound changes to maintain productivity whilst promoting sustainability and resilience of the agro-systems [2]. In the context of promoting crop productivity and sustainability, irrigated agriculture may be one of the main suitable options against climate change [3-5]. An increase in irrigation demand, with the corresponding impact on energy consumption and GHG emissions, will lead to potential conflicts in terms of mitigation and adaptation policies [6,7].

Agricultural sustainability must be monitored based on adequate indicators. The Spanish Ministry of Agriculture, in its Annual Report of Indicators [8], considers GHG emission as an adequate indicator to provide an integrative vision of the agricultural sector sustainability. From the perspective of climate change and its mitigation, agriculture can contribute to both climate change and its mitigation. In the agricultural sector, GHG emissions come from the applied production techniques as well as from provided inputs (i.e., fertilisers, agrochemicals, irrigation water supply, energy supply). However, agriculture represents a carbon sink, capturing atmospheric $\mathrm{CO}_{2}$ into the plant mass and the soil. Consequently, an analysis of the carbon footprint in agriculture needs to determine the carbon balance 
between GHG emission and $\mathrm{CO}_{2}$ removal. A negative balance implies that the activity captures more $\mathrm{CO}_{2}$ than it emits and therefore can be considered sustainable from a climate perspective. However, a positive balance implies the need to seek mitigation strategies such as innovative production techniques and alternative inputs to achieve sustainability.

Life Cycle Assessment (LCA) is a reference method to quantitatively evaluate the environmental impact across the entire supply chain in terms of energy-use efficiency, environmental effects and sustainability, including GHG emissions as a relevant indicator of global warming potential. For agri-food systems, LCA is increasingly being used to evaluate and analyse environmental and food security issues [9,10], including crop production [11,12], contributing to the creation of scientific knowledge for evidence-based policy-making [13].

Irrigated agriculture constitutes the largest consumer of freshwater in the water-scarce Mediterranean region and provides a major source of income and employment for rural livelihoods [14]. However, increasing droughts and water scarcity are jeopardising the availability and reliability of water resources for irrigation [15]. This is a limiting factor for economic development and has highlighted concerns regarding the environmental sustainability of agriculture in the region [16]. In this context, inter-basin water transfers are instruments of water planning that can play an important role in mitigating water scarcity and the effects of climate change [17].

Our study focuses on irrigated lands associated with the Tagus-Segura water transfer (TSWT); a 292-km-long canal that has transferred flows since 1979 from the Tagus headwaters river basin in central Spain, to the Segura River basin (SRB) in south-eastern (SE) Spain $[18,19]$. The SRB, despite being hot and dry, has witnessed remarkable agricultural development over the last decades, becoming one of the world's leading producers of fruits and vegetables [20]. An important part of this highly profitable business relies almost exclusively on the TSWT. Pellicer-Martínez and Martínez Paz [21] studied the possible effects that the latest climate change scenarios may have on the TSWT and predicted important reductions in snowfalls and snow covers, the recharge of aquifers and, consequently, the available water resources in the headwaters of the Tagus River basin. Moreover, the importance of water ecosystem services in the Tagus River basin has progressively been highlighted in recent years. The latter involves increasing demands to satisfy and safeguard multiple needs of consumers, the economy and the environment. Consequently, the decrease in water available for the transfer has led to bitter regional disputes [22]. Past and present perspectives on the SRB water shortage are well documented [19,23].

This chronic and problematic situation has driven the orientation of Spanish water policy since the beginning of the 21st century towards the widespread adoption of nonconventional water resources. Particular emphasis has been given to desalination as an alternative to other water supply options such as river regulation or new inter-basin water transfers [24]. As a result, massive seawater desalinisation has been implemented in the last decade as an alternative way to increase urban and agricultural supplies in SE Spain [23]. Seawater desalination effectively removes the climatological and hydrological constraints associated with continental water resources [25]. In addition, it circumvents the social and inter-regional conflicts associated with river regulation through dam building and long-distance inter-basin water transfers [26]. In such a way, desalination is alleviating the decrease in the water supplied by the TSWT in recent years. The downside is that the specific energy consumption for desalinated seawater (DSW) supply in the SRB ( $4.32 \mathrm{kWh}$ $\mathrm{m}^{-3}$ [27]) is much higher than that of the TSWT (1.21 $\mathrm{kWh} \mathrm{m}^{-3}$ [28]). This increases the GHG emissions of irrigated agriculture and jeopardises the effectiveness of climate change control policies.

Given the importance of irrigated agriculture in SE Spain, this study provides robust and objective estimates on GHG emissions under different scenarios, in which the TSWT supply is partially and fully replaced with DSW. Furthermore, in order to highlight the potential role of regional agriculture as a carbon sink, the $\mathrm{CO}_{2}$ removals associated with 
the irrigation lands were estimated. Finally, potential ways to improve the sustainability of the agricultural use of DSW are proposed.

\section{Materials and Methods}

The analysis of the carbon footprint for the study area was developed in two phases: (1) the determination of the GHG emissions and $\mathrm{CO}_{2}$ removals for the most representative crops in the study area; and (2) their extrapolation to the irrigation districts supplied by the TSWT to obtain global figures of the carbon balance.

Agricultural production data was used to estimate the carbon footprint for the most representative fruit and vegetable crops in the study area. In order to estimate the GHG emissions, LCA methodology has been applied, following the protocols standardised by the International Standards Organization in the ISO 14040 [29] and ISO 14044 [30] standards. Crop $\mathrm{CO}_{2}$ removal rates were obtained from the results of experimental trials in the region published by other authors, as detailed in Section 2.4.

Several studies have found that irrigation water conveyance and application emit large amounts of GHGs [31-33]. Therefore, the carbon footprint was calculated under three water supply scenarios, in which there was a progressive replacement of the water supply from the TSWT with DSW. This is the main strategy included in the Spanish water planning to redress the persistent water deficit affecting irrigation in the SRB. Therefore, the sensitivity of the results for this variable is of special interest to analyse the carbon footprint implications of the planned agricultural water supply. Finally, we compare our results with other related studies.

\subsection{Segura River Basin (SRB) and Tagus-Segura Water Transfer (TSWT)}

The SRB is a highly productive agricultural region in SE Spain, whose economy is built primarily on the export of high-value vegetables and fruits. Its semiarid climate is characterised by hot, dry summers and sporadic intense rains in autumn. The mildtemperature winters allow vegetables to be grown in the open field. This area, with high-return agriculture, is usually referred to as 'the orchard of Europe' [34], since exports of horticultural products to EU countries may exceed $70 \%$ of the total production. It plays a major role in the basin's economy in terms of production and employment.

The SRB is one of the most water-stressed regions in the Mediterranean basin. The official estimation [35] is that the SRB water resources amount to $1602 \mathrm{Mm}^{3}$ /year, which includes water transferred from central Spain through the inter-basin TSWT (322 $\mathrm{Mm}^{3} /$ year) and DSW (158 $\mathrm{Mm}^{3} /$ year produced in several desalination plants [27]). These resources fail to satisfy a total water demand of $1834 \mathrm{Mm}^{3} /$ year, which includes $1546 \mathrm{Mm}^{3}$ /year for irrigated agriculture ( $84 \%$ of the total). The mean annual water deficit amounts to about $400 \mathrm{Mm}^{3}$ [35], threatening the strategic agricultural production and bolstering conflicts between aggravated users [22]. The water shortage and conflicts explain the massive seawater desalination strategy implemented in the SRB by the Spanish government to guarantee the urban supply as well as foster irrigated agriculture [23].

The TSWT is one of the largest $(292 \mathrm{~km})$ inter-basin infrastructures in southern Europe. The rationale for developing that water transfer was that cities and tourism on the Mediterranean coast needed water to grow and that irrigated agriculture in the mild regions of SE Spain could achieve higher water productivity than in the inner regions. The TSWT is managed by its own operational rules, which give priority to the water uses in the Tagus River basin and depend on the volume stored in the Tagus headwaters reservoirs. As indicated in the official estimation of the SRB resources [35], currently and on average, barely $60 \%$ of the approved flows can be transferred. Such a decrease in the annual transferred flow is a situation that is predicted to intensify in the future as the pressure of climate change mounts in the Tagus River basin [21,36].

The increasing water shortage mainly affects irrigated agriculture, which currently amounts to 262,393 ha in the SRB, and has led to a serious problem of overexploitation in many aquifers [37]. The supply to farmers is organised by irrigation districts, which 
can be differentiated into two types: those using the water resources generated in the SRB, named 'traditional irrigation districts'; and, conversely, those that are mainly supplied by the TSWT, named 'Tagus-Segura irrigation districts'. Our study targets the latter, which represents a net irrigated area of 98,923.6 ha organised into 18 Agricultural Demand Units (ADUs), as shown in Figure 1. They are particularly important in the SRB economy, in terms of both production value and employment (2000 M EUR/year and 58,500 annual work units, respectively [35]).

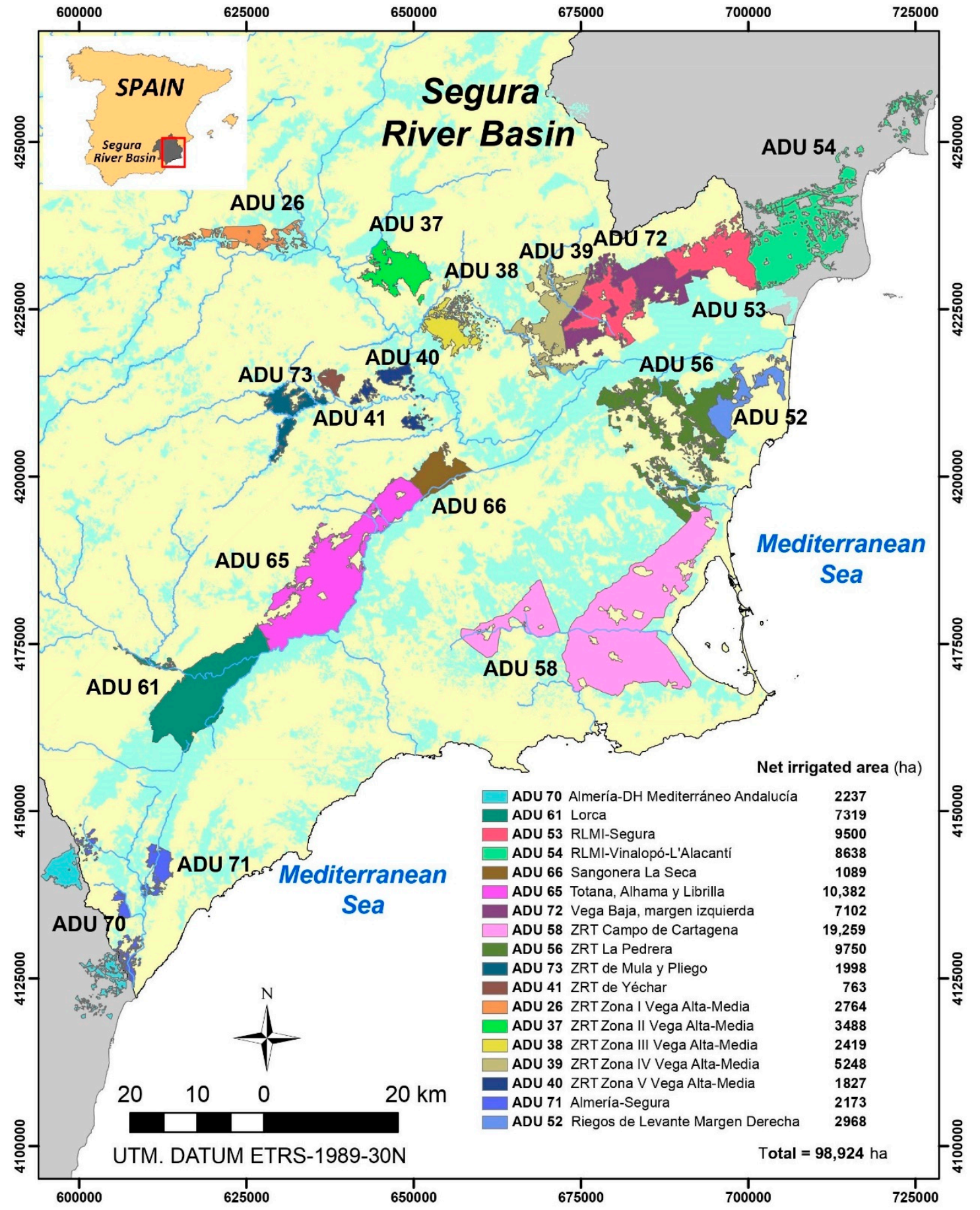

Figure 1. Study area and Agricultural Demand Units (ADUs) supplied by the Tagus-Segura water transfer (TSWT). 


\subsection{Water Supply Scenarios and Water-Energy Nexus}

Irrigation activity is the main water and energy consumer in the production of irrigated crops under the agroclimatic conditions of the SRB. Agriculture in the SRB is supplied with water from different sources: superficial, ground, reclaimed, transferred and desalinated waters. The origin of the irrigation water is a key factor in the specific energy $\left(\mathrm{kWh} / \mathrm{m}^{3}\right)$ associated with the supply [38]. In accordance, the following three water supply scenarios were considered:

- Concession scenario (WS0). This is a theoretical scenario corresponding to the irrigation rights recognised in the Hydrological Plan of the Segura Demarcation 2015/21 for the ADUs linked to the TSWT [35], without considering recent desalination concessions (13 $\mathrm{Mm}^{3}$ /year). The water resources' availability for this scenario are shown in Figure 2. The specific consumption associated with the supply in WS0 is $0.94 \mathrm{kWh} / \mathrm{m}^{3}$.

- Current scenario (WS1). This corresponds to the irrigation rights recognised in the Hydrological Plan of the Segura Demarcation 2015/21 for the ADUs linked to the TSWT, adjusting the TSWT supply to its average value for the period 1979 to 2011 (196 Mm $\mathrm{Mm}^{3}$ /year in origin and $176 \mathrm{Mm}^{3}$ /year in destination [39]); and the DSW to current concessions $\left(13 \mathrm{Mm}^{3}\right.$ /year included in the Hydrological Plan and $80 \mathrm{Mm}^{3}$ /year assigned from the Torrevieja desalination plant, according to the Official State Gazette of 3 October 2019). This scenario is quite representative of the current situation due to the aforementioned progressive decrease in the transferred flow through the TSWT. The specific consumption associated with the supply in WS1 is $1.41 \mathrm{kWh} / \mathrm{m}^{3}$.

- Substitution scenario of TSWT with seawater desalination (WS2). As shown in Figure 2, this is the same scenario as the Concession Scenario (WS0) but replacing $100 \%$ of the TSWT with DSW. It represents a hypothetical future scenario that could occur because of the multiple pressures on the TSWT. The specific consumption associated with WS3 is $2.78 \mathrm{kWh} / \mathrm{m}^{3}$.

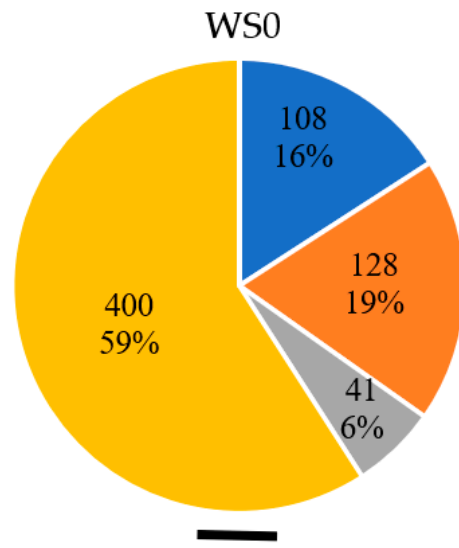

$0.9 \mathrm{~kW} \cdot \mathrm{h} / \mathrm{m}^{3}$

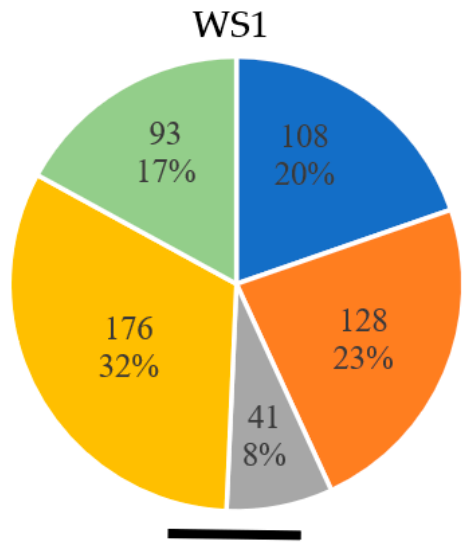

$1.5 \mathrm{~kW} \cdot \mathrm{h} / \mathrm{m}^{3}$

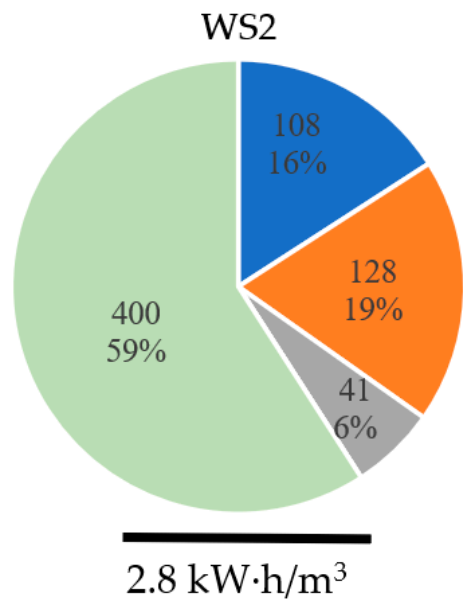

$2.8 \mathrm{~kW} \cdot \mathrm{h} / \mathrm{m}^{3}$

Figure 2. Mix of water sources $\left(\mathrm{Mm}^{3} /\right.$ year) and the specific energy $\left(\mathrm{kWh} / \mathrm{m}^{3}\right)$ by supply scenario. WS0: Concession scenario; WS1: Current scenario; WS2: Substitution scenario of TSWT with desalinated seawater (DSW).

The specific consumption values for each scenario were calculated based on the percentage of water provided by each source for this scenario (Figure 2) and their associated specific consumption (the calculation is included in Table S1 of the Supplementary Materials).

\subsection{Main Crops Considered in the Study}

Estimating GHG emissions for a crop requires all the information regarding the farming work and provided inputs, as well as the necessary infrastructure of the plot. The estimation of $\mathrm{CO}_{2}$ removal usually requires samples to be taken from complete plant individuals in order to determine the carbon content of all their organs. Therefore, having 
all this information for all the crop species developed in the ADUs linked to the TSWT is not a straightforward process and is often only accessible for the most relevant crops. Nine crops were selected as being the most representative since they cover the largest area in the case studied.

The selected crops were organised into three groups (outdoor vegetables, citrus and non-citrus fruit) in order to comply with the classification of crops in the Hydrological Plan of the Demarcation of Segura 2015/21 for the description of the ADUs:

- Outdoor vegetables. This group is made up of artichoke, broccoli, lettuce and melon. Their covered area in the region represents $84.42 \%$ of the total cultivated vegetables area [40] (see Table S2 in the Supplementary Materials).

- Citrus. Lemon, mandarin and orange were considered. Their covered area in the region represents $97.78 \%$ of the total cultivated citrus area [40] (see Table S3 in the supplement for details).

- Non-citrus fruits (fleshy fruits). Apricot and peach were considered. Their covered area in the region represents $88.02 \%$ of the total cultivated non-citrus area [40] (see Table S4 in the supplement for details).

Table 1 shows the net area by crop group in the set of ADUs associated with the TSWT. The share was $27.81 \%$ for outdoor vegetables, $45.83 \%$ for citrus and $12.30 \%$ for non-citrus fruits, covering a total of $85.94 \%$ of the irrigated area in the case studied.

Table 1. Net area by crop group in the set of ADUs associated with the TSWT [34].

\begin{tabular}{ccc}
\hline Crop & Surface Area (ha) & Percentage (\%) \\
\hline Citrus & $45,339.5$ & 45.83 \\
Vegetables, outdoor & $27,509.9$ & 27.81 \\
Non-citrus (fleshy fruit) & $12,165.3$ & 12.30 \\
Olive & 3638.3 & 3.7 \\
Almond & 2975.8 & 3.0 \\
Cereals, winter & 2161.8 & 2.2 \\
Vegetables, protected & 2198.1 & 2.2 \\
Grapes, table & 1704.5 & 1.7 \\
Grapes, wine & 864.8 & 0.9 \\
Tuber (potato) & 241.2 & 0.2 \\
Cereals, spring (maize) & 51.1 & 0.1 \\
Lucerne & 44.1 & 0.1 \\
Cotton & 29.3 & 0.1 \\
Total & $98,923.6$ & 100.00 \\
\hline
\end{tabular}

\subsection{Carbon Footprint ( $\mathrm{CO}_{2}$ Balance)}

The carbon footprint was determined as the difference between the GHG emissions related with farm operations and $\mathrm{CO}_{2}$ (biogenic carbon) removal by crops. Throughout the study, the following sign criterion was considered: positive for carbon transfers from agricultural activity to the atmosphere and negative when transfers occur in the opposite direction. Therefore, GHG emissions have a positive sign, the removal of $\mathrm{CO}_{2}$ has a negative sign and the balance sign is the result of the sum of those flows.

In order to determine GHG emissions related with farming operations, the LCA methodology was applied, following the protocols standardised by the ISO 14040/14044 standard series [29,30]. GHG emissions were estimated following the IPCC $2013 \mathrm{v} 1.03$ (time frame of 100 years) methodology from the Intergovernmental Panel on Climate Change [41] and expressed as $\mathrm{CO}_{2}$ eq using the most recent IPPC emission factors [42].

The biogenic carbon dioxide fixation was estimated following ISO 14067 [43] and reported in terms of $\mathrm{CO}_{2}$. According to ISO 14067, when calculating the carbon footprint for a product's entire life cycle all the emissions and removals (biogenic and fossil) must be considered, regardless of the crop cycle length. Details of biogenic carbon dioxide fixation by crops were obtained from Carvajal et al. [44], who presented information for 
most crops in SE Spain. The carbon sequestration in the soil could not be quantified and hence considered due to current lack of data, like the actual influence of tillage, organic amendments and crop rotation on the carbon storage.

\subsubsection{Calculation of GHG Emissions by Life Cycle Assessment (LCA) Methodology}

In order to determine GHG emissions related with farming operations, the LCA results obtained in a manuscript recently published by the authors [33] were considered. LCA was used to quantify the environmentally relevant flows of the most important fruit and vegetable production systems in SE Spain from several perspectives: depletion of elements and fossil fuels, acidification and eutrophication hazards, global warming potential and use of water resources. An LCA sensitivity analysis was used in this study to estimate the variation in the GHG emissions, considering the specific energy from the supply scenarios defined above (Section 2.2).

The functional unit was the cultivation of one hectare, throughout one year. The crop cycle length was one year for citrus (lemon, orange and mandarin) and non-citrus (apricot and peach) woody crops, and artichoke; six months for broccoli; and four months for lettuce and melon. In order to compare results between crops throughout one year, the following five annual crop rotations of outdoor vegetables were considered, because they are the most frequent and representative in the study area (information provided by the "Campo de Cartagena" Irrigation District, www.crcc.es): (1) lettuce-lettuce; (2) lettuce-broccoli; (3) lettuce-melon; (4) broccoli-melon; (5) artichoke. We considered the average value obtained from those crop rotations as being the annual value per hectare for outdoor vegetables.

More detailed information regarding the LCA carried out can be found in the Supplementary Materials, including (i) the system boundaries for the cradle-to-gate production of vegetable and woody crops (Figure S1), (ii) the description of the agricultural stages (Table S5) and (iii) the LCA inventory for the studied crops (Tables S6 and S7). In addition, the surface area by crop group in each ADU (Table S8) and the annual values of the carbon balance in each ADU (Tables S9 and S10) are provided.

\subsubsection{Calculation of $\mathrm{CO}_{2}$ Removal by Crops}

The biogenic carbon dioxide fixation by crops was obtained from the study by Carvajal et al. [44], which analysed the potential for $\mathrm{CO}_{2}$ removal for the main agricultural and forestry species in the region. Table 2 shows the carbon removal values $\left(\mathrm{t} \mathrm{CO}_{2} / \mathrm{ha}\right)$ of the crops under study.

Table 2. Annual values of $\mathrm{CO}_{2}$ fixation $\left(\mathrm{kg} \mathrm{CO}_{2}\right)$ per plant and per hectare and planting density (plant/ha) of the main vegetables and woody crops cultivated in the region [43].

\begin{tabular}{|c|c|c|c|c|}
\hline Crop Group & Crop & $\begin{array}{c}\mathrm{CO}_{2} \text { Fixation } \\
\text { (kg CO} 2 / \text { Plant) }\end{array}$ & $\begin{array}{c}\text { Planting Density } \\
\text { (Plant/ha) }\end{array}$ & $\begin{array}{c}\mathrm{CO}_{2} \text { Fixation } \\
\left.\text { (t } \mathrm{CO}_{2} / \mathrm{ha}\right)\end{array}$ \\
\hline \multirow[t]{4}{*}{ Outdoor vegetables } & Artichoke & -1.854 & 7000 & -12.98 \\
\hline & Broccoli & -0.239 & 35,000 & -8.37 \\
\hline & Lettuce & -0.130 & 65,000 & -8.45 \\
\hline & Melon & -0.802 & 10,000 & -8.02 \\
\hline \multirow[t]{3}{*}{ Citrus } & Lemon & -106.93 & 280 & -29.94 \\
\hline & Mandarin & -31.11 & 420 & -13.06 \\
\hline & Orange & -49.35 & 420 & -20.73 \\
\hline \multirow{2}{*}{ Non-citrus (fleshy fruit) } & Apricot & -84.49 & 204 & -17.24 \\
\hline & Peach & -49.77 & 570 & -28.37 \\
\hline
\end{tabular}




\subsection{Extrapolation of Results to ADUs Supplied by the TSWT}

A Geographic Information System (ESRI ArcGIS) was used to extrapolate the values previously obtained to the entire target area. The steps followed in the extrapolation process can be summarised as follows:

1. Determination of the annual values of GHG emissions, $\mathrm{CO}_{2}$ removal and carbon balance for each crop group and water scenario. For the "citrus" and "non-citrus" fruit groups the value was calculated using the weighted average by the area of each crop of the selected group in the region (see Tables S3 and S4 for details). In the case of the "outdoor vegetables" group, the average value obtained from the five most frequent and representative crop rotations in the study area was considered as an annual value per hectare (Section 2.4.1).

2. Determination of the weight of each crop group in each ADU. The percentages that each group of crops represents in each ADU were considered (data included in Table S8 of the Supplementary Materials). Then, the net area corresponding to the crop groups was calculated, increasing it in proportion to its magnitude until the total net area of each ADU was reached.

3. Determination of the total ( $\mathrm{t} \mathrm{CO}_{2}$ eq $/$ year) and specific ( $\mathrm{t} \mathrm{CO}_{2 \text { eq }} /$ ha-year) annual GHG emissions per ADU and water scenario. From the GHG emissions values calculated for each crop group, the value corresponding to each ADU was obtained by multiplying that value by the weight of the crop group in the $\mathrm{ADU}\left(\mathrm{t} \mathrm{CO}_{2}\right.$ eq $/$ ha-year) and by the net area of the $\mathrm{ADU}$ ( $\mathrm{tCO}_{2}$ eq $/$ year). This process was repeated for each water scenario.

4. Determination of the total ( $\mathrm{CO}_{2}$ /year) and specific ( $\mathrm{t} \mathrm{CO} 2 /$ ha-year) annual $\mathrm{CO}_{2}$ removal and carbon balance per ADU. The same procedure described in step 3 was followed.

5. Aggregation and graphic representation of the entire study area results for each water scenario. The estimation of the total and specific annual values of GHG emissions, $\mathrm{CO}_{2}$ removal and carbon balance were carried out by adding the values obtained for each ADU and water scenario. Finally, those values were graphically presented to show their spatial trends.

\section{Results and Discussion}

\subsection{Carbon Balance of the Selected Crops}

The GHG emissions, $\mathrm{CO}_{2}$ removal and carbon balance for the selected crops and scenarios are presented in Figure 3. Overall and regardless of the scenario, the vegetables show greater variability of GHG emissions than the woody crops. The cultivation of vegetables annually emitted $7.96 \pm 2.73,9.18 \pm 3.31$ and $12.77 \pm 5.03 \mathrm{t} \mathrm{CO}_{2 \mathrm{eq}} /$ ha for scenarios WS0, WS1 and WS2, respectively, whereas the figures for the woody crops were $8.37 \pm 0.98,9.37 \pm 1.03$ and $12.30 \pm 1.21 \mathrm{t} \mathrm{CO}_{2}$ eq $/ \mathrm{ha}$. For both the vegetables and the woody crops, the greatest GHG sources came from irrigation, field operations and fertilisers. In the case of vegetables, those stages amounted to $88.3,89.9$ and $92.0 \%$ of the total emissions in WS0, WS1 and WS2, respectively. The annual values for woody crops were somewhat similar: 91.7, 92.6 and 94.4\%, respectively. Our results about the important contribution of irrigation practices in GHG emissions were in agreement with those reported by other authors for the Mediterranean region. Persiani et al. [45] found that the highest energy-consuming inputs for a cauliflower-lettuce rotation in southern Italy were irrigation followed by fertilisers; and the highest GHG emissions were for water and fertilisers. In this respect, Martin-Gorriz et al. [33] proposed and evaluated mitigation strategies to reduce GHG emissions for crops in SE Spain. The most promising impact-mitigation action was the replacement of mineral fertiliser with manure, which offered potential GHG emissions reductions of up to 10 and $21 \%$ for vegetable and woody crops, respectively. 


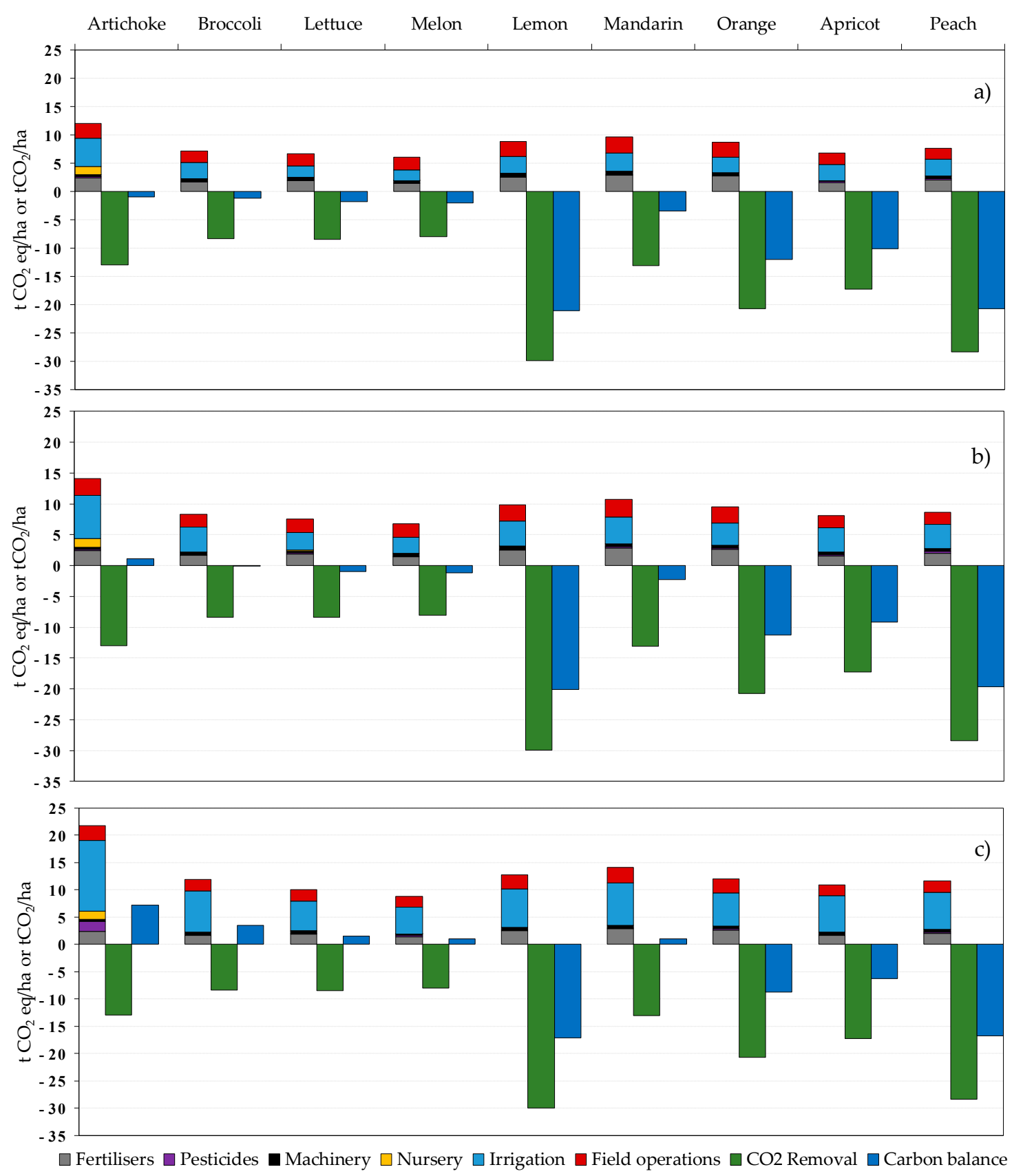

Figure 3. Greenhouse gas (GHG) emissions by crop (expressed as the contribution by stages: fertilisers, pesticides, machinery, nursery, irrigation and field operations), $\mathrm{CO}_{2}$ removal and carbon balance for the three scenarios; (a) WS0, (b) WS1 and (c) WS2.

With regard to $\mathrm{CO}_{2}$ removal, the annual values for the three scenarios were $-9.46 \pm 2.36$ and $-21.87 \pm 7.21 \mathrm{tCO}_{2} / \mathrm{ha}$ for the vegetables and the woody crops, indicating that the outdoor vegetables fixed a notably smaller amount than the woody crops. This can be explained by the higher leaf area index and the longer use of the land in woody crops, which stay and fix carbon throughout the whole year. Artichoke was the exception, with its $\mathrm{CO}_{2}$ removal value being $50 \%$ higher than that for the rest of the vegetables, as shown in Figure 3.

In the Concession Scenario (WS0, Figure 3a), the annual emissions from the vegetables ranged from $6.05 \mathrm{tCO}_{2}$ eq $/$ ha (melon) to $12.01 \mathrm{t} \mathrm{CO}_{2}$ eq $/$ ha (artichoke). Irrigation accounted for $36.7 \%$, which can be attributed to the fossil fuel combustion to produce electricity to transport water; fertilisers accounted for $23.3 \%$, which is attributed to the electricity used 
for its production; whilst field operations accounted for $28.3 \%$, associated to the diesel consumption by machinery. In the case of the woody crops, the emissions ranged from $7.12 \mathrm{t} \mathrm{CO}_{2}$ eq $/$ ha (apricot) to $9.60 \mathrm{t} \mathrm{CO}_{2}$ eq $/$ ha (mandarin). In this case, irrigation, fertilisers and field operations represented $35.2,27.7$ and $28.9 \%$, respectively. In this scenario, all the crops acted as a $\mathrm{CO}_{2}$ sink. On average, the balance for the woody crops was about nine times more favourable than for the vegetables $(-13.49 \pm 7.48$ vs. $-1.49 \pm 0.46 \mathrm{t}$ $\mathrm{CO}_{2} / \mathrm{ha}$ ). The lemon crop presented the most negative balance and artichoke had the least negative balance.

The current scenario (WS1, Figure $3 b$ ) showed a rise in specific energy consumption from $0.94 \mathrm{kWh} / \mathrm{m}^{3}$ in WS0 to $1.41 \mathrm{kWh} / \mathrm{m}^{3}$, which implies an increase in the emissions for all the crops. For the vegetables, such increases ranged from $12 \%$ (lettuce and melon) to $17 \%$ (artichoke and broccoli). In WS1, irrigation, fertilisers and field operations accounted for 45.0, 20.2, 24.6\% GHG emissions, respectively. In the case of the woody crops, such increases ranged from $12 \%$ (citrus) to $14 \%$ (fleshy fruits). In this case, irrigation accounted for $42.1 \%$, fertilisers for $24.7 \%$ and field operations for $25.8 \%$ of the total GHG emissions. All the crops continued to act as a $\mathrm{CO}_{2}$ sink, except for artichoke and broccoli. Artichoke became a source of carbon $\left(1.09 \mathrm{t} \mathrm{CO}_{2} /\right.$ ha, i.e., its farming practices emitted more $\mathrm{CO}_{2}$ into the atmosphere than that captured by the crop), whereas broccoli presented an almost neutral balance $\left(-0.06 \mathrm{t} \mathrm{CO}_{2} / \mathrm{ha}\right)$. On average, the balance was about 45 times more favourable for the woody crops than for the vegetables $(-12.50 \pm 7.52$ vs. $-0.27 \pm 1.03 \mathrm{t}$ $\mathrm{CO}_{2} / \mathrm{ha}$ ). Lemon was again the crop with the most negative balance.

Regarding the hypothetical substitution of TSWT with DSW (WS2, Figure 3c), the specific energy reached $2.78 \mathrm{kWh} / \mathrm{m}^{3}$ and the GHG emissions were again higher. For the vegetables, lettuce and melon GHG emissions increased by 50\% (lettuce-melon rotation) to $68 \%$ (artichoke-broccoli rotation) compared to WSO. Of the total GHG emissions, irrigation accounted for $60.5 \%$ of GHG emissions, which is attributed to the fossil fuel combustion for electricity to produce and transport water; fertilisers accounted for $14.5 \%$ and field operations for $17.0 \%$. In the case of the woody crops, emissions increased range from $45 \%$ (citrus) to 53\% (fleshy fruits). In this case, irrigation accounted for $55.8 \%$, fertilisers for $18.8 \%$ and field operations for $19.7 \%$ of the total. In WS2, only the woody crops continued to be net carbon fixers $\left(-9.57 \pm 7.62 \mathrm{t} \mathrm{CO}_{2} / \mathrm{ha}\right)$, whereas all the vegetables acted as a $\mathrm{CO}_{2}$ source $\left(3.31 \pm 2.75 \mathrm{tCO}_{2} / \mathrm{ha}\right)$, with artichoke being the crop with the highest carbon balance $\left(7.14 \mathrm{t} \mathrm{CO}_{2} / \mathrm{ha}\right)$ and melon the one with the lowest $\left(1.05 \mathrm{t} \mathrm{CO}_{2} / \mathrm{ha}\right)$.

The annual values of GHG emissions, $\mathrm{CO}_{2}$ removal and carbon balance per crop group and scenario are summarised in Table 3 . The carbon balance became less favourable for the environment as the specific energy $\left(\mathrm{kWh} / \mathrm{m}^{3}\right)$ of the water supply intensified due to the progressive incorporation of DSW (WS0 $\rightarrow$ WS1 $\rightarrow$ WS2). The per-hectare analysis showed that the GHG emissions for the outdoor vegetables were $60 \%$ higher than for the woody crops in WSO. This is mainly attributed to the higher implementation of inputs in the vegetables [33]. Such a percentage increased up to 70\% in WS2 due to the higher use of DSW for irrigation. Thus, $\mathrm{CO}_{2}$ removal by the vegetables was always lower than that of the woody crops. As a result of both behaviours, the annual carbon balance of the vegetables was 6 (WS0) to 17 (WS2) times lower than for the woody crops. This circumstance means that outdoor vegetables went from being a carbon sink in WS0 to being a carbon source in WS2. Therefore, the woody crops were demonstrated to be more effective in mitigating climate change than the vegetables, but on the other hand, they are riskier crops for farmers since they are more sensitive to suffering drought in the long term [46]. 
Table 3. Annual values of GHG emissions, $\mathrm{CO}_{2}$ removal and $\mathrm{CO}_{2}$ balance per crop group and scenario.

\begin{tabular}{|c|c|c|c|c|}
\hline Water Scenario & Crop Group & $\begin{array}{l}\text { GHG Emissions } \\
\text { (t CO } \mathrm{CO}_{2 \text { eq }} \text { /ha-Year) }\end{array}$ & $\begin{array}{c}\mathrm{CO}_{2} \text { Removal } \\
\text { (t CO } \mathrm{CO}_{2} \text { /ha-Year) }\end{array}$ & $\begin{array}{c}\mathrm{CO}_{2} \text { Balance } \\
\text { (t CO} 2 \text { /ha-Year) }\end{array}$ \\
\hline \multirow[t]{3}{*}{ W0 } & Outdoor vegetables * & 13.02 & -15.91 & -2.89 \\
\hline & Citrus & 8.91 & -25.56 & -16.65 \\
\hline & Non-citrus fruit & 7.47 & -24.08 & -16.60 \\
\hline \multirow[t]{3}{*}{ W1 } & Outdoor vegetables * & 14.90 & -15.91 & -1.01 \\
\hline & Citrus & 9.91 & -25.56 & -15.65 \\
\hline & Non-citrus fruit & 8.46 & -24.08 & -15.62 \\
\hline \multirow[t]{3}{*}{ W2 } & Outdoor vegetables * & 20.43 & -15.91 & 4.52 \\
\hline & Citrus & 12.87 & -25.56 & -12.69 \\
\hline & Non-citrus fruit & 10.96 & -24.08 & -12.72 \\
\hline
\end{tabular}

* Average values for the most frequent annual crop rotations: (1) lettuce-lettuce; (2) lettuce-broccoli; (3) lettuce-melon; (4) broccoli-melon; (5) artichoke. Note that the values for each crop are provided in Figure 3.

\subsection{Carbon Balance by Agricultural Demand Units (ADUs)}

Once the annual values of carbon balance per crop group (Table 3$)$, as well as the weight of each group in the ADUs were estimated (Table S8), the total $\left(\mathrm{t}_{2} /\right.$ year) and the specific ( $\mathrm{t} \mathrm{CO}_{2}$ /ha-year) annual carbon balances were calculated within each ADU for the selected scenarios (Figure 4). The results are given in Tables S6 and S7 for total and specific annual values, respectively.

Figure $4 \mathrm{a}, \mathrm{c}$,e represent the total GHG emissions, $\mathrm{CO}_{2}$ removals and carbon balance for the WS0, WS1 and WS2 scenarios, respectively. For WS0 and WS1, all ADUs had a negative carbon balance, which demonstrates the $\mathrm{CO}_{2}$ sink role of irrigated agriculture in the study area under concessional and current water supply conditions. The absolute magnitude of the carbon balances in Figure $4 a$, c, e were mainly driven by ADU size, though crop composition played a role (as shown more clearly in $4 \mathrm{~b}, 4 \mathrm{~d}$ and $4 \mathrm{f}$ ). The relative magnitude of an individual ADU among the three scenarios showed the increasing rate of GHG emissions with the progressive incorporation of DSW. Consequently, the total carbon balance in each ADU lessened when passing from WS0 to WS1 and lessened still further for WS2, where ADUs 61, 70 and 71 presented a positive total carbon balance, i.e., they became sources of carbon. Therefore, the substitution of TSWT supply with DSW can change the role of irrigated agriculture from being a carbon sink to being a carbon source under certain conditions, which are analysed below.

Figure $4 \mathrm{~b}, \mathrm{~d}, \mathrm{f}$ represent the specific (per hectare) carbon balance for WS0, WS1 and WS2 scenarios, respectively. A spatial trend of the specific carbon balance value could be appreciated for all scenarios. It clearly decreased from north to south, but also varied more subtly from inland to the coast. This variation is related to the crop groups prevailing in the ADUs (Table S8). Since the southern and coastal zones in the study area present milder winter conditions and warmer springs, they are far more suitable for winter outdoor vegetables (broccoli and lettuce) and for early muskmelon crops during the spring-summer season, for which it is desirable to advance the cultivation date looking for better market prices. Therefore, the ADUs located in the southern and coastal areas were those with a higher proportion of outdoor vegetables (ADUs 58, 61, 70 and 71 had from 58 to $79 \%$ of total surface area) and, consequently, those with a less favourable specific carbon balance. On the contrary, the woody crops were those with a more favourable specific carbon balance (Table 3) and they predominate in inland and northern ADUs. Non-citrus trees (fleshy fruits) were those that better tolerated winter cold, which is essential for the proper development of their annual fruiting cycle, so they are mainly located in more inland ADUs (ADUs 26, 37, 38, 40, 41 and 73 had from 54 to $86 \%$ of total surface area), justifying their higher specific carbon balance values. Finally, citrus predominate in the northern area (ADUs $39,52,53,54,65$ and 72 had from 53 to $83 \%$ of total surface area), where mild conditions throughout the year (coastal effect leading to the absence of frost in winter and very high temperatures in summer) favour their productive cycle. Therefore, the spatial 
trend of the specific carbon balance value was related to the prevailing location of crops, explaining the positive total and specific carbon balances of southern ADUs in WS2. The latter became a carbon source due to the predominance of the only crop group presenting a positive $\mathrm{CO}_{2}$ balance: outdoor vegetables. It should also be highlighted that citrus, having shown one of the most negative carbon balances in all scenarios and hence being one of the most environmentally sustainable crops, is also one of the crops with a lower economic net margin per cubic metre, as reported in Martínez-Alvarez et al. [23], thus pinpointing that citrus is the crop whose economy would be most affected by the implementation of an agricultural supply where DSW was the predominant water source.
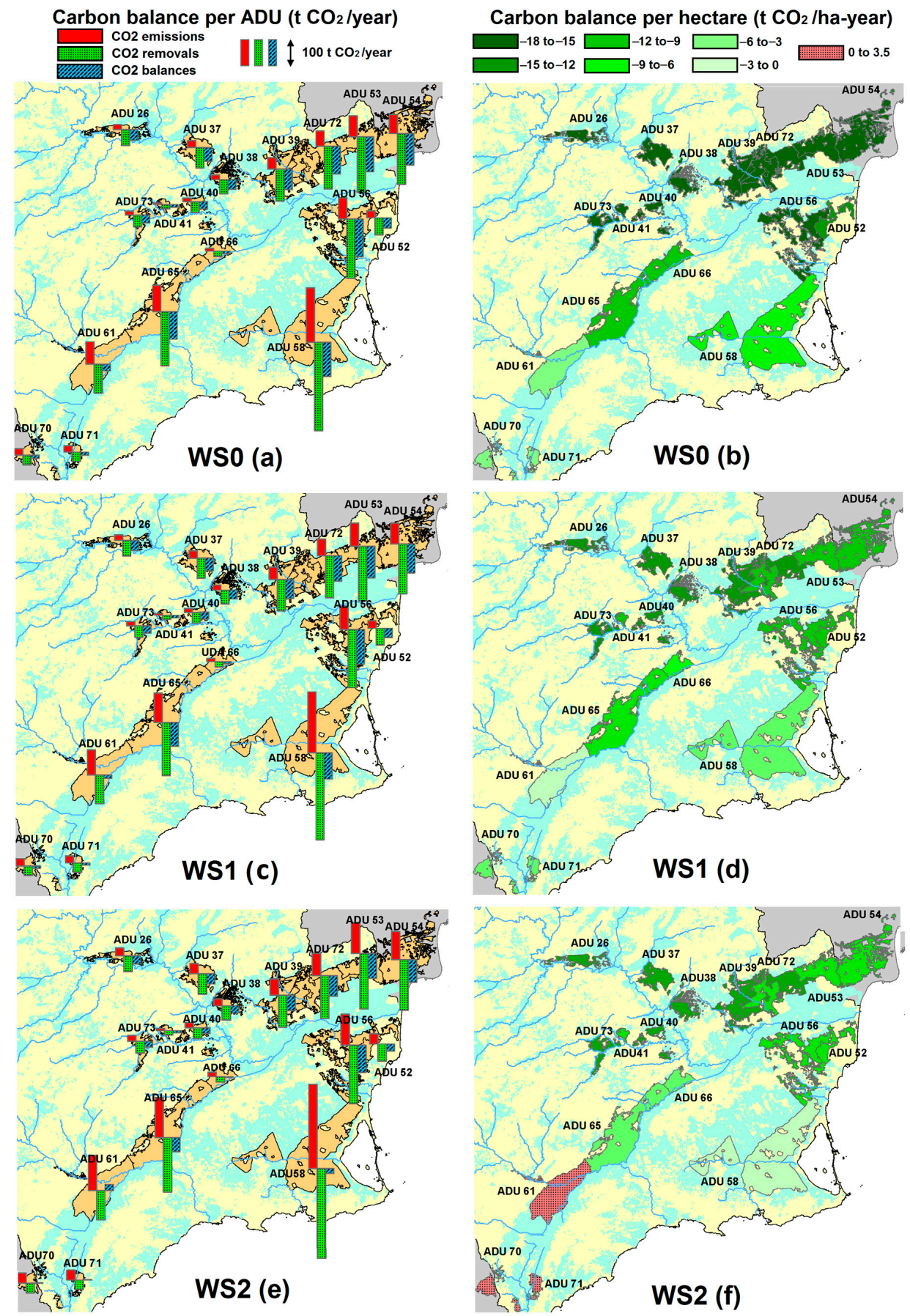

Figure 4. Total carbon balance per $\mathrm{ADU}\left(\mathrm{t} \mathrm{CO}_{2}\right.$ /year; $\left.\mathbf{a}, \mathbf{c}, \mathbf{e}\right)$ and specific carbon balance $\left(\mathrm{t} \mathrm{CO}_{2} /\right.$ ha-year; $\left.\mathbf{b}, \mathbf{d}, \mathbf{f}\right)$ within each ADU for the considered scenarios: WS0 (a,b), WS1 (c,d) and WS2 (e,f). 


\subsection{Carbon Balance of the Irrigation Lands Supplied by the TSWT}

Table 4 shows the total and specific GHG emissions, $\mathrm{CO}_{2}$ removal and carbon balance for the net irrigated area associated with the TSWT (98,923.6 ha), obtained by adding the values for each ADU and scenario.

Table 4. Total and specific annual GHG emissions, $\mathrm{CO}_{2}$ removal and carbon balance for the net irrigated area associated with the TSWT for the considered scenarios.

\begin{tabular}{|c|c|c|c|}
\hline Scenario & GHG Emissions & $\mathrm{CO}_{2}$ Removal & $\mathrm{CO}_{2}$ Balance \\
\hline WS0 & & & \\
\hline Total (t CO 2 eq $/$ year) & 991,744 & $-2,177,828$ & $-1,208,084$ \\
\hline $\begin{array}{c}\text { Specific (t } \mathrm{CO}_{2 \text { eq }} / \text { ha-year) } \\
\text { WS1 }\end{array}$ & 9.61 & -22.57 & -12.96 \\
\hline Total (t CO $\mathrm{CO}_{2} /$ year $)$ & $1,118,748$ & $-2,177,828$ & $-1,081,080$ \\
\hline $\begin{array}{c}\text { Specific (t } \mathrm{CO}_{2} \text { eq } / \text { ha-year) } \\
\text { WS2 }\end{array}$ & 10.84 & -22.57 & -11.73 \\
\hline Total (t CO 2 eq /year) & $1,492,552$ & $-2,177,828$ & $-707,276$ \\
\hline Specific (t $\mathrm{CO}_{2}$ eq $/$ ha-year) & 14.47 & -22.57 & -8.10 \\
\hline
\end{tabular}

Overall, the results show that the irrigated area associated with the TSWT acted as an important carbon sink regardless of the scenario. This decreasing capacity as a carbon sink was inversely proportional to the increase in specific energy due to the growing percentage of DSW in the irrigation mix (from $0.94 \mathrm{kWh} / \mathrm{m}^{3}$ in WS0 to $2.78 \mathrm{kWh} / \mathrm{m}^{3}$ in WS2). In fact, irrigation was responsible for $36 \%$ of the $\mathrm{CO}_{2}$ eq emissions in WS0, with that figure increasing to 45.0 and $60.5 \%$ in the WS1 and WS2 scenarios, respectively.

These figures indicate that, although the incorporation of massive DSW supply to irrigated agriculture can enhance its resilience in the face of water shortages, such a strategy does reduce its mitigating role against the increasing $\mathrm{CO}_{2}$ concentration in the atmosphere. Improved sustainability of irrigated agriculture is needed to compensate for this undesirable effect. This aspect is discussed below.

\section{Adaptation Strategies to Increase Sustainability}

At the EU level, agriculture has been responsible for $10 \%$ of the GHG emissions in the last decade [47]. That figure reaches $12 \%$ in the case of Spain [48]. Irrigation is currently responsible for $45.0 \%$ of the GHG emissions in the irrigation districts linked to the TSWT (WS1 scenario), although this could increase to $60.5 \%$ in the near future (WS2). Some of the following strategies can be considered for dealing with that potential increase to foster sustainability of the DSW agricultural use:

1. Controlled blending of DSW with other water sources. This has been documented in several countries, including Israel [49-52]; Spain [27,53-55]; Mexico [56,57]; USA (California) [58-60]; and Australia [61]. In Israel for example, blending 36\% of DSW with other water sources (groundwater, surface water and brackish water) reduced GHG emissions by $53 \%$ compared to $100 \%$ DSW [52]. In the case of La Marina seawater desalination plant in Almería (south of Spain), mixing the DSW with groundwater did help remineralise DSW whilst significantly reducing the associated environmental impact [27]. In SE Spain, Martínez-Alvarez et al. [62] evaluated the impact of irrigation with DSW on farming costs and fertiliser requirements for different crops, concluding that blending DSW and conventional water at a 50\% rate notably reduced the operational costs (mainly linked with energy consumption) and the fertiliser application, although that study did not estimate its associated positive environmental impact.

2. Increasing renewable energy sources in electricity mix production. Reducing GHG emissions associated with the electricity mix to produce DSW is another important strategy to increase the sustainability of DSW for irrigation. Of all industry sectors, electricity is responsible for the largest fraction (25\%) of global anthropogenic GHG emissions [1]. The share of renewable energies in global electricity generation approached $26 \%$ in 
2018 [63] and reached 32\% in the European Union [64]. In September 2020, the European Commission proposed raising the 2030 GHG emission reduction target to at least 55\% compared to 1990. Achieving this target requires: (i) an increased share for renewable energy of at least 32\% and (ii) an improvement in energy efficiency of at least $32.5 \%$ [65]. In line with these policy targets, the integration of renewable energy into DSW production may substantially reduce its carbon footprint. In fact, Shahabi et al. [66] indicated that seawater desalination plants powered with renewable energy can achieve a $90 \%$ reduction in GHG emissions. Numerous other authors have stressed the importance of increasing renewable energy in the production of electricity to improve the sustainability of horticulture [33,67,68]. Torrellas et al. [67] indicated that the current overexploitation of aquifers in water-scarce areas, such as SE Spain, has promoted the use of non-conventional water resources such as DSW. That is why electricity consumption has increased around eightfold in these cultivation cases, using $100 \%$ of DSW for irrigation. Therefore, renewable energies are important in counterbalancing farming electricity consumption increases, as MartinGorriz et al. [55] highlighted in a study on greenhouse tomato production irrigated with DSW, where a $53 \%$ increase in the use of renewable energy in the production of electricity led to a $17 \%$ reduction in GHG emissions.

3. Improving water use efficiency. Improving irrigation water use efficiency contributes to cutting down the energy consumption for water management and irrigation in the same proportion. In this sense, in the last 10 years the water consumption by irrigation in Spain fell by 15\% [69]; and in 2018 the water volume applied by drip irrigation in Spain was $53 \%$, reaching $86 \%$ in the case of the ADUs linked to the TSWT [70]. These data show the commitment of practitioners (farmers and technicians) in the study area to a more sustainable and efficient agriculture. On the one hand, advances in irrigation systems as well as new technologies, such as wireless sensor networks and remote sensing tools, can be applied to further improve irrigation efficiency in vegetables and woody crops [71,72]. Consequently, it is possible to reduce energy consumption whilst improving water use efficiency through comprehensive irrigation management. In such a way, Gonzalez Perea et al. [73] achieved a 15\% reduction in energy consumption by implementing more efficient irrigation and water management practices, with no significant yield reduction. Qureshi [74], improving on-farm irrigation management, achieved a $40 \%$ reduction in $\mathrm{CO}_{2}$ emissions in Pakistan. Cvejic et al. [75] also reduced the irrigation-volume consumption by $25 \%$ and the GHG emissions by $24 \%$, through the adoption of irrigation-decision support systems tools in Vipava Valley (Slovenia). On the one hand, prioritising crops with lower water footprints and higher dietary efficiency, provided they are still profitable for farmers, is key to reduce the water demand. A recent study looking at the water footprint of 50 Mediterranean crops (including most of the crops of this study) demonstrated the importance of selecting agro-systems not only based on the irrigation efficiency but also accounting for the crop dietary efficiency as well as the economic productivity and efficiency [76].

4. Adoption of soil carbon sequestration practices. Organic amendments, residue incorporation, reduced tillage or crop rotation can reach 4 per mille or even higher soil carbon sequestration rates [77]. Organic amendment additions represent direct inputs of organic carbon into the soil systems. In Mediterranean woody crops a combination of inter-row plant covers with organic amendments like pruning residues have been reported to be a successful carbon sequestration practice [78]. For Mediterranean vegetable crops, rotations that include agro-ecological service crops combined with the addition of green manure have been demonstrated to be very efficient in terms of carbon sequestration [79]. Tillage reduction implies higher crop residue retention and lower fuel consumption [80,81], but it is environmentally beneficial only if not replaced by polluting herbicides. Overall, the key aspect here is the fact that the $\mathrm{CO}_{2}$ captured from the atmosphere and incorporated into the plants stays within in the agro-systems with these practices, rather than being released back to the atmosphere. 


\section{Conclusions}

The present study estimates the carbon footprint of the irrigated lands supplied by the TSWT in SE Spain, quantifying their carbon balance as the difference between GHG emissions from agricultural activities and $\mathrm{CO}_{2}$ removals due to planted crops. The study focuses on how the source of the water supply for irrigation can influence the GHG emissions of farming activity and, consequently, its carbon footprint. In order to determine this, the irrigated agriculture of the study area has been analysed under three water supply scenarios involving a progressive substitution of the TSWT supply by DSW.

Our results show that GHG emissions for crops depend largely on water sources and, consequently, their carbon footprint. Among the crops, the woody crops have a more favourable specific carbon balance (per hectare) than outdoor vegetables from an environmental perspective. This can be mainly attributed to the lower implementation of inputs in woody crops. The incorporation of DSW to crop irrigation enhances the energy consumption linked to the water supply, which could change the role of outdoor horticultural crops from a carbon sink to a carbon source.

The irrigated area associated with the TSWT acts as an important carbon sink, regardless of the scenario. However, its sink capacity diminishes in proportion to the increase in the specific energy of water supply, due to the growing percentage of DSW in the irrigation mix. In this sense, a complete substitution of the TSWT supply by DSW (WS2) might increase GHG emissions by up to $50 \%$ and reduce the carbon balance by $41 \%$.

This trend is particularly marked in some irrigation districts where outdoor vegetables are the prevailing crops; they become carbon sources with a positive net carbon balance $\left(\mathrm{CO}_{2}\right.$ removals $<\mathrm{CO}_{2}$ eq emissions) in the hypothetical scenario of complete substitution of the TSWT supply by DSW (WS2). Therefore, substituting the TSWT supply with DSW can change the role of irrigated agriculture from a carbon sink to a carbon source under specific circumstances, such as the prevalence of outdoor horticultural crops. Moreover, the spatial trend of the specific carbon balance is also related to the prevailing location of the crops; the northern and inland irrigation districts, where the agroclimatic conditions are more suitable for woody crops (citrus and fleshy fruits), are proved to be more favourable than the southern irrigation districts, where milder winters favour the production of outdoor horticultural crops.

Our results show that, although the incorporation of DSW supply to irrigated agriculture can enhance its resilience in the presence of water shortages, thereby supporting the associated socioeconomic development, it decreases its $\mathrm{CO}_{2}$ sink role and consequently, its climate change mitigating potential. To compensate for this, some potential ways to improve the sustainability of the agricultural DSW use are proposed: blending DSW with other water sources; boosting the renewable energies rate in the electricity mix production; a comprehensive improvement of water use efficiency; adopting soil carbon sequestration practices. Farmers and technicians in the study area are becoming increasingly aware of these measures, but their application should be encouraged by agricultural policies to achieve a more efficient and sustainable agriculture.

Supplementary Materials: The following are available online at https:/ / www.mdpi.com/2073-4 395/11/2/351/s1: Table S1. Water resources and specific energy contributions to irrigation mix by scenario. Table S2. Surface area and percentage of outdoor vegetables in the region in 2017. Table S3. Surface area and percentage of citrus in the region in 2017. Table S4. Surface area and percentage of non-citrus (fleshy fruit) in the region in 2017. Figure S1. System boundaries for cradle-to-gate production of vegetable and woody crops (citrus fruits and non-citrus trees). Table S5. Agricultural stages of Life Cycle Assessment. Table S6. Life Cycle Inventory for the vegetable crops of the study. Table S7. Life Cycle Inventory for the woody crops (citrus and non-citrus trees) of the study. Table S8. Percentage of surface area by crop group in each ADU. Table S9. Total annual values of carbon balance in each ADU for the considered scenarios. Table S10. Annual values of carbon balance per hectare in each ADU for the considered scenarios. 
Author Contributions: The four authors have contributed equally to the methodology implementation, data acquisition, data analysis and derived conclusions. All authors have revised and approved the final manuscript. All authors have read and agreed to the published version of the manuscript.

Funding: This study was promoted and funded by the Cátedra Trasvase y Sostenibilidad-Jose Manuel Claver Valderas of the Technical University of Cartagena. The study was also supported by the Ministerio de Economía, Industria y Competitividad (MINECO), the Agencia Estatal de Investigación (AEI) and the Fondo Europeo de Desarrollo Regional (FEDER) under the projects RIDESOST (AGL2017-85857C2-2-R) and SEARRISOST (RTC-2017-6192-2). Gallego-Elvira acknowledges the support from The Ministry of Science, Innovation and University ("Beatriz Galindo" Fellowship BEAGAL18/00081).

Institutional Review Board Statement: Not applicable.

Informed Consent Statement: Not applicable.

Data Availability Statement: Data sharing not applicable.

Conflicts of Interest: The authors declare no conflict of interest.

\section{References}

1. IPCC. Intergovernmental Panel on Climate Change. Climate Change. Synthesis Report. Contribution of Working Groups I, II and III to the Fifth Assessment Report of the Intergovernmental Panel on Climate Change; Pachauri, R.K., Meyer, L.A., Eds.; IPCC: Geneva, Switzerland, 2014; p. 151.

2. Food and Agriculture Organization of the United Nations (FAO). The Future of Food and Agriculture: Trends and Challenges; FAO: Rome, Italy, 2017.

3. Hanjra, M.; Qureshi, M.E. Global water crisis and future food security in an era of climate change. Food Policy 2010, 35, 365-377. [CrossRef]

4. Knox, J.W.; Hess, T.M.; Daccache, A.; Wheeler, T. Climate change impacts on crop productivity in Africa and South Asia. Environ. Res. Lett. 2012, 7, 034032. [CrossRef]

5. Tumushabe, J.T. Climate Change, food security and sustainable development in Africa. In The Palgrave Handbook of African Politics, Governance and Development; Oloruntoba, S.O., Falola, T., Eds.; Palgrave Macmillan US: New York, NY, USA, 2018 ; pp. 853-868.

6. Fedoroff, N.V.; Battisti, D.S.; Beachy, R.N.; Cooper, P.J.M.; Fischhoff, D.A.; Hodges, C.N.; Knauf, V.C.; Zhu, J.K. Radically rethinking agriculture for the twenty-first century. Science 2010, 327, 833-834. [CrossRef]

7. Carrillo Cobo, M.T.; Camacho, E.; Montesinos, P.; Rodríguez Díaz, J.A. Assessing the potential of solar energy in pressurized irrigation networks. The case of Bembezar MI irrigation district (Spain). Span. J. Agric. Res. 2014, 3, 838-849. [CrossRef]

8. Ministerio de Agricultura Pesca y Alimentación. Informe Anual de Indicadores 2018; MAGRAMA: Madrid, Spain, 2019.

9. Soussana, J.F. Research priorities for sustainable agri-food systems and life cycle assessment. J. Clean. Prod. 2014, 73, 19-23. [CrossRef]

10. Viaggi, D. Research and innovation in agriculture: Beyond productivity? Bio-Based Appl. Econ. 2015, 4, $279-300$.

11. Venkat, K. Comparison of twelve organic and conventional farming systems: A life cycle greenhouse gas emissions perspective. J. Sustain. Agric. 2012, 36, 620-649. [CrossRef]

12. Aguilera, E.; Guzmán, G.; Alonso, A. Greenhouse gas emissions from conventional and organic cropping systems in Spain. I. Herbaceous crops. Agron. Sustain. Dev. 2015, 35, 713-724. [CrossRef]

13. Sonnemann, G.; Gemechu, E.D.; Sala, S.; Schau, E.M.; Allacker, K.; Pant, R.; Adibi, N.; Valdivia, S. Life cycle thinking and the use of LCA in policies around the world. In Life Cycle Assessment; Hauschild, M.Z., Rosenbaum, R.K., Olsen, S.I., Eds.; Springer International Publishing: Cham, Switzerland, 2018.

14. Daccache, A.; Ciurana, J.S.; Rodriguez Diaz, J.A.; Knox, J.W. Water and energy footprint of irrigated agriculture in the Mediterranean region. Environ. Res. Lett. 2014, 9, 124014. [CrossRef]

15. Shrestha, S.; Shrestha, M.; Babel, M.S. Assessment of climate change impact on water diversion strategies of Melamchi Water Supply Project in Nepal. Theor. Appl. Climatol. 2017, 128, 311-323. [CrossRef]

16. Soto-García, M.; Martínez-Alvarez, V.; Martin-Gorriz, B. El Regadío en la Región de Murcia. Caracterización y Análisis Mediante Indicadores de Gestion; SCRATS: Murcia, Spain, 2014. (In Spanish)

17. Zhang, E.; Yin, X.; Xu, Z.; Yang, Z. Bottom-up quantification of inter-basin water transfer vulnerability to climate change. Ecol. Indic. 2018, 92, 195-206. [CrossRef]

18. Garrido, A.; Martínez-Santos, P.; Llamas, M.R. Groundwater irrigation and its implications for water policy in semi-arid countries: The Spanish experience. Hydrogeol. J. 2006, 14, 340-349. [CrossRef]

19. Grindlay, A.L.; Zamorano, M.; Rodríguez, M.I.; Molero, E.; Urrea, M.A. Implementation of the European Water Framework Directive: Integration of hydrological and regional planning at the Segura River Basin, southeast Spain. Land Use Policy 2011, 28, 242-256. [CrossRef]

20. Impacto Económico del Trasvase Tajo-Segura. SCRATS. Available online: http://www.scrats.es/ftp/memorias/Impactoeconomico-trasvase-Tajo-Segura.pdf (accessed on 24 January 2021). 
21. Pellicer-Martinez, F.; Martínez-Paz, J.M. Climate change effects on the hydrology of the headwaters of the Tagus River: Implications for the management of the Tagus-Segura transfer. Hydrol. Earth Syst. Sci. 2018, 22, 6473-6491. [CrossRef]

22. Fleskens, L.; Nainggolan, D.; Termansen, M.; Hubacek, K.; Reed, M.S. Regional consequences of the way land users respond to future water availability in Murcia, Spain. Reg. Environ. Chang. 2013, 13, 615-632. [CrossRef]

23. Martínez-Alvarez, V.; González-Ortega, M.J.; Martin-Gorriz, B.; Soto-García, M.; Maestre Valero, J.F. The use of desalinated seawater for crop irrigation in the Segura River Basin (south-eastern Spain). Desalination 2017, 364, 2-16. [CrossRef]

24. Swyngedouw, E.; Williams, J. From Spain's hydro-deadlock to the desalination fix. Water Int. 2016, 41, 54-73. [CrossRef]

25. Feitelson, E.; Rosenthal, G. Desalination, space and power: The ramifications of Israel's changing water geography. Geoforum 2012, 43, 272-284. [CrossRef]

26. March, H.; Saurí, D.; Rico-Amorós, A.M. The end of scarcity? Water desalination as the new cornucopia for Mediterranean Spain. J. Hydrol. 2014, 519, 2642-2651. [CrossRef]

27. Martínez-Alvarez, V.; Maestre-Valero, J.F.; González-Ortega, M.J.; Gallego-Elvira, B.; Martin-Gorriz, B. Characterization of the agricultural supply of desalinated seawater in Southeastern Spain. Water 2019, 11, 1233. [CrossRef]

28. Melgarejo, J.; Montaño, B. La eficiencia energética del trasvase Tajo-Segura. Cuides 2009, 9, 173-193.

29. International Organization for Standardization, ISO-14040. Environmental Management_Life Cycle Assessment—Principles and Framework; ISO: Geneva, Switzerland, 2006.

30. International Organization for Standardization, ISO-14044. Environmental Management_Life Cycle Assessment—Requirements and Guidelines; ISO: Geneva, Switzerland, 2006.

31. Karimi, P.; Qureshi, A.S.; Bahramloo, R.; Molden, D. Reducing carbon emissions through improved irrigation and groundwater management: A case study from Iran. Agric. Water Manag. 2012, 108, 52-60. [CrossRef]

32. Zou, X.; Li, Y.; Li, K.; Cremades, R.; Gao, Q.; Wan, Y.; Qin, X. Greenhouse gas emissions from agricultural irrigation in China. Mitig. Adapt. Strateg. Glob. Chang. 2015, 20, 295-315. [CrossRef]

33. Martin-Gorriz, B.; Gallego-Elvira, B.; Martínez-Alvarez, V.; Maestre-Valero, J.F. Life cycle assessment of fruit and vegetable production in the Region of Murcia (south-east Spain) and evaluation of impact mitigation practices. J. Clean. Prod. 2020, 265, 121656. [CrossRef]

34. Maestre-Valero, J.F.; Martínez-Granados, D.; Martínez-Alvarez, V.; Calatrava, J. Socio-economic impact of evaporation losses from reservoirs under past, current and future water availability scenarios in the semi-arid Segura basin. Water Resour. Manag. 2013, 27, 1411-1426. [CrossRef]

35. Confederación Hidrográfica de la Cuenca del Segura (CHS). Plan Hidrológico de la Cuenca del Segura 2015-2021; CHS: Murcia, Spain, 2015. (In Spanish)

36. Centro de Estudios y Experimentación de Obras Públicas (CEDEX). Evaluación del Impacto del Cambio Climático en los Recursos Hidricos en Régimen Natural; CEDEX: Madrid, Spain, 2011. (In Spanish)

37. Rodriguez-Estrella, T. The problems of overexploitation of aquifers in semi-arid areas: The Murcia Region and the Segura Basin (South-east Spain) case. Hydrol. Earth Syst. Sci. Discuss. 2012, 9, 5729-5756.

38. Soto-García, M.; Martin-Gorriz, B.; García-Bastida, P.A.; Alcon, F.; Martínez-Alvarez, V. Energy consumption for crop irrigation in a semiarid climate (south-eastern Spain). Energy 2013, 55, 1084-1093. [CrossRef]

39. Confederación Hidrográfica del Segura (CHS). Available online: https://www.chsegura.es/export/sites/chs/descargas/ planificacionydma/planificacion/docsdescarga/Anejo_02_Recursos_Hidricos.pdf (accessed on 25 January 2021).

40. Centro Regional de Estadística de Murcia (CREM). Available online: http://econet.carm.es/inicio/-/crem/sicrem/PU_ datosBasicos/sec49.htm (accessed on 27 June 2019).

41. IPCC. Guidelines for national greenhouse gas inventories. In Prepared by National Greenhouse Gas Inventories Programme; Eggleston, H.A.S., Biennia, L., Miwa, K., Negara, T., Tanabe, K., Eds.; Eggleston Published IGES: Hayama, Japan, 2006.

42. Myhre, G.; Shindell, D.; Bréon, F.M.; Collins, W.; Fuglestvedt, J.; Huang, J.; Zhang, H. Anthropogenic and natural radiative forcing. In Climate Change 2013: The Physical Science Basis. Contribution of Working Group I to the Fifth Assessment Report of the Intergovernmental Panel on Climate Change; Stocker, T.F., Qin, D., Plattner, G.K., Tignor, M., Allen, S.K., Boschung, J., Midgley, P.M., Eds.; Cambridge University Press: Cambridge, UK; New York, NY, USA, 2013; pp. 659-740.

43. International Organization for Standardization, ISO-14067. Greenhouse Gases e Carbon Footprint of Products e Requirements and Guidelines for Quantification and Communication; ISO: Geneva, Switzerland, 2013.

44. Carvajal, M.; Mota, C.; Alcaraz-López, C.; Iglesias, M.; Martínez-Ballesta, M.C. Investigación sobre la absorción de CO 2 por los cultivos más representativos de la Región de Murcia. In Etiquetado de Carbono en Las Explotaciones y Productos Agrícolas. la Iniciativa Murciana Como Sumidero de $\mathrm{CO}_{2}$; Victoria, F., Ed.; CARM: Murcia, Spain, 2010; pp. 65-91. Available online: http:/ / www.lessco2.es/documentacion.htm (accessed on 20 November 2020). (In Spanish)

45. Persiani, A.; Diacono, M.; Monteforte, A.; Montemurro, F. Agronomic performance, energy analysis, and carbon balance comparing different fertilization strategies in horticulture under Mediterranean conditions. Environ. Sci. Pollut. Res. 2019. [CrossRef]

46. Ballester, C.; Castel, J.; Abd El-Mageed, T.A.; Castel, J.R.; Intrigliolo, D.S. Long-term response of 'Clementina de Nules' citrus trees to summer regulated deficit irrigation. Agric. Water Manag. 2014, 138, 78-84. [CrossRef]

47. Eurostat. Agri-Environmental Indicator-Greenhouse Gas Emissions 2019. Available online: https:/ / ec.europa.eu/eurostat/ statisticsexplained/ (accessed on 20 November 2020). 
48. COP25, Agricultura y Ganadería Frente al Cambio Climático. Available online: https://www.upa.es/upa/actualidad/cop25/ (accessed on 20 November 2020).

49. Yermiyahu, U.; Tal, A.; Ben-Gal, A.; Bar-Tal, A.; Tarchitzky, J.; Lahav, O. Rethinking desalinated water quality and agriculture. Science 2007, 318, 920-921. [CrossRef]

50. Avni, N.; Eben-Chaime, M.; Oron, G. Optimizing desalinated sea water blending with other sources to meet magnesium requirements for potable and irrigation waters. Water Res. 2013, 47, 2164-2176. [CrossRef]

51. Meron, N.; Blass, V.; Garb, Y.; Kahane, Y.; Thoma, G. Why going beyond standard LCI databases is important: Lessons from a metaanalysis of potable water supply system LCAs. Int. J. Life Cycle Assess. 2016, 21, 1134-1147. [CrossRef]

52. Meron, N.; Blass, V.; Thoma, G. A national-level LCA of a water supply system in a Mediterranean semi-arid climate-Israel as a case study. Int. J. Life Cycle Assess. 2020, 25, 1133-1144. [CrossRef]

53. Díaz, F.J.; Tejedor, M.; Jiménez, C.; Grattan, S.R.; Dorta, M.; Hernández, J.M. The imprint of desalinated seawater on recycled wastewater: Consequences for irrigation in Lanzarote island, Spain. Agric. Water Manag. 2013, 116, 62-72. [CrossRef]

54. Martin-Gorriz, B.; Maestre-Valero, J.F.; Martínez-Alvarez, V. Assessing water supply sources using life cycle assessment: Study case of lemon crop in Southeastern Spain. In Proceedings of the European Agricultural Engineering Conference, AgEng 2018, Wageningen, The Netherlands, 8-12 July 2018.

55. Martin-Gorriz, B.; Gallego-Elvira, B.; Maestre-Valero, J.F.; Membrive, P.M.; Terrero, P.; Martínez-Álvarez, V. Recycling drainage effluents using reverse osmosis powered by photovoltaic solar energy in hydroponic tomato production: Environmental footprint analysis. J. Environ. Manage. 2021. under review.

56. González-Bravo, R.; Napoles-Rivera, F.; Ponce-Ortega, J.M.; El-Halwagi, M. Involving integrated seawater desalination-power plants in the optimal design of water distribution networks. Resour. Conserv. Recycl. 2015, 104, 181-193. [CrossRef]

57. Hipólito-Valencia, B.J.; Mosqueda-Jiménez, F.W.; Barajas-Fernández, J.; Ponce-Ortega, J.M. Incorporating a seawater desalination scheme in the optimal water use in agricultural activities. Agric. Water Manag. 2021, 244, 106552. [CrossRef]

58. Bell, E.M.; Stokes-Draut, J.R.; Horvath, A. Environmental evaluation of high-value agricultural produce with diverse water sources: Case study from Southern California. Environ. Res. Lett. 2018, 13, 025007. [CrossRef]

59. Welle, P.D.; Medellín-Azuara, J.; Viersc, J.H.; Meagan, S.; Mauter, M.S. Economic and policy drivers of agricultural water desalination in California's central valley. Agric. Water Manag. 2017, 194, 192-203. [CrossRef]

60. Qin, Y.; Horvarth, A. Use of alternative water sources in irrigation: Potential scales, costs, and environmental impacts in California. Environ. Res. Commun. 2020, 2, 0550032020. [CrossRef]

61. Barron, O.; Ali, R.; Hodgson, G.; Smith, D.; Qureshi, E.; McFarlane, D.; Campos, E.; Zarzo, D. Feasibility assessment of desalination application in Australian traditional agriculture. Desalination 2015, 364, 33-45. [CrossRef]

62. Martínez-Alvarez, V.; Gallego-Elvira, B.; Maestre-Valero, J.F.; Martin-Gorriz, B.; Soto-Garcia, M. Assessing concerns about fertigation costs with desalinated seawater in south-eastern Spain. Agric. Water Manag. 2020, 239, 106257. [CrossRef]

63. Renewables 2019. Global Status Report. Global Overview—Ren21. Available online: www.ren21.net/gsr-2020/chapters/chapter_ 01/chapter_01/ (accessed on 27 June 2019).

64. European Commission. 2030 Climate \& Energy Framework. 2020. Available online: https://ec.europa.eu/clima/policies/ strategies/2030_en\#tab-0-0 (accessed on 20 November 2020).

65. European Commission. 2020. Available online: https://ec.europa.eu/info/strategy/priorities-2019-2024/european-green-deal/ actions-being-taken-eu_en (accessed on 27 June 2020).

66. Shahabi, M.P.; McHugh, A.; Anda, M.; Ho, G. Environmental life cycle assessment of seawater reverse osmosis desalination plant powered by renewable energy. Renew. Energy 2014, 67, 53-58. [CrossRef]

67. Torrellas, M.; Antón, A.; López, J.C.; Baeza, E.J.; Parra, J.P.; Muñoz, P.; Montero, J.I. LCA of a tomato crop in a multi-tunnel greenhouse in Almeria. Int. J. Life Cycle Assess. 2012, 17, 863-875. [CrossRef]

68. Martinez-Mate, M.A.; Martin-Gorriz, B.; Martínez-Alvarez, V.; Soto-García, M.; Maestre-Valero, J.F. Hydroponic system and desalinated seawater as an alternative farm-productive proposal in water scarcity areas: Energy and greenhouse gas emissions analysis of lettuce production in southeast Spain. J. Clean. Prod. 2018, 172, 1298-1310. [CrossRef]

69. Federación Nacional de Comunidades de Regantes (FENACORE). Available online: https://www.europapress.es/sociedad/ medio-ambiente-00647/noticia-consumo-agua-riego-redujo-15-hectarea-ultimos-10-anos-fenacore-20190322141954.html (accessed on 22 June 2020).

70. Instituto Nacional de Estadística. Encuesta so.bre el uso del agua en el se.ctor agrari.o (EUASA) Año 2018. Available online: https: / / www.ine.es/prensa/euasa_2018.pdf (accessed on 27 June 2020).

71. Hamami, L.; Nassereddine, B. Application of wireless sensor networks in the field of irrigation: A review. 2020. Comput. Electron. Agr. 2020, 179, 105782. [CrossRef]

72. Zinkernagel, J.; Maestre-Valero, J.F.; Seresti, S.Y.; Intrigliolo, D.S. New technologies and practical approaches to improve irrigation management of open field vegetable crops. Agric. Water Manag. 2020, 242, 106404. [CrossRef]

73. Gonzalez Perea, R.; Camacho Poyato, E.; Montesinos, P.; Rodriguez Diaz, J.A. Optimization of irrigation scheduling using soil water balance and genetic algorithms. Sustain. Water Resour. Manag. 2016, 30, 2815-2830. [CrossRef]

74. Qureshi, A.S. Reducing carbon emissions through improved irrigation management: A case study from Pakistan. Irrig. Drain. 2014, 63, 132-138. [CrossRef] 
75. Cvejić, R.; Černič-Istenič, M.; Honzak, L.; Pečan, U.; Železnikar, Š.; Pintar, M. Farmers Try to Improve Their Irrigation Practices by Using Daily Irrigation Recommendations-The Vipava Valley Case, Slovenia. Agronomy 2020, 10, 1238. [CrossRef]

76. Kahramanoğlu, İ.; Usanmaz, S.; Alas, T. Water footprint and irrigation use efficiency of important crops in Northern Cyprus from an environmental, economic and dietary perspective. Saudi J. Biol. Sci. 2020, 27, 134-141. [CrossRef]

77. Minasny, B.; Malone, B.P.; McBratney, A.B.; Angers, D.A.; Arrouays, D.; Chambers, A.; Chaplot, V.; Winowiecki, L. Soil carbon 4 per mille. Geoderma 2017, 292, 59-86. [CrossRef]

78. Vicente-Vicente, J.L.; García-Ruiz, R.; Francaviglia, R.; Aguilera, E.; Smith, P. Soil carbon sequestration rates under Mediterranean woody crops using recommended management practices: A meta-analysis. Agric. Ecosyst. Environ. 2016, 235, 204-214. [CrossRef]

79. Farina, R.; Testani, E.; Campanelli, G.; Leteo, F.; Rosario Napoli, R.; Canali, S.; Tittarelli, F. Potential carbon sequestration in a Mediterranean organic vegetable cropping system. A model approach for evaluating the effects of compost and Agro-ecological Service Crops (ASCs). Agric. Syst. 2018, 162, 239-248. [CrossRef]

80. Govaerts, B.; Verhulst, N.; Castellanos-Navarrete, A.; Sayre, K.D.; Dixon, J.; Dendooven, L. Conservation agriculture and soil carbon sequestration: Between myth and farmer reality. Crit. Rev. Plant Sci. 2009, 28, 97-122. [CrossRef]

81. Martin-Gorriz, B.; Maestre-Valero, J.F.; Almagro, M.; Boix-Fayos, C.; Martínez-Mena, M. Carbon emissions and economic assessment of farm operations under different tillage practices in organic rainfed almond orchards in semiarid Mediterranean conditions. Sci. Hortic. 2020, 261, 108978. [CrossRef] 